\title{
STUDIES IN THE PHYSIOLOGY OF ARTIFICIAL FEVER. I. CHANGES IN THE BLOOD VOLUME AND WATER BALANCE
}

\author{
By JOHN G. GIBSON, 2D,1 AND ISRAEL KOPP 2 \\ (From the Department of Medicine, Harvard University, the Medical Clinic of the Peter Bent \\ Brigham Hospital, and the Department of Neurosyphilis of the Boston Psychopathic \\ Hospital, Boston)
}

(Received for publication December 7, 1937)

During recent years great interest has been aroused in the use of artificially induced fever in the treatment of disease. Numerous claims have been made for the benefits of fever therapy but very little attention has been paid to the changes it brings about in the coordinated functions of the body, well and diseased.

The dangers of fever therapy have been emphasized by many authors. Reactions of varying severity from nausea and vomiting to tetany (1, $2,3)$, delirious episodes (4), convulsions (5), heat stroke (3) and shock $(2,3,6,7,8)$, have been described and deaths have been reported $(9,10,11,12,13,14)$.

The purpose of the studies reported in this series of communications was to determine the changes resulting from artificially induced fever in circulating blood volume, water balance, acidbase equilibrium, and hemodynamics and the relationship of these changes to the clinical condition of the patient. Our studies on the first two of these factors are reported herein.

No thorough studies on changes in blood volume during artificial fever have been reported. In the opinion of several fever therapists (15, $16,17)$ no significant alterations in circulating blood volume occur during artificial fever if water is given liberally, although some workers have reported that some degree of blood concentration does occur $(18,19,20)$. Hemoconcentration as evidenced by increases in red counts and hemoglobin values has been regarded by some as evidence of a reduction in volume $(19,20)$, but others (15) interpret the increase in hemoglobin as evidence of a real increase in total hemoglobin to meet increased oxygen requirements. By means of the CO method (21) and a dye method

\footnotetext{
1 Research Fellow in Medicine, Harvard Medical School.

2 Research Associate in the Massachusetts Department of Mental Diseases.
}

(22), decreases in plasma volume have been observed after artificially induced fever in animals.

Reliable studies of the water balance in artificial fever were not found in the literature, although the high fluid requirement amounting to as much as 3 to 6 liters during a 5 to 6 hour treatment has been commented on $(15,23)$.

\section{METHODS}

The dye method of determining the plasma and total blood volume of Gibson and Evans (24) was used. In the experiments conducted in Rochester, N. Y., and Dayton, Ohio, colorimetry was done by the technique described by Gibson and Evelyn (25) with the photoelectric colorimeter of Evelyn and Cipriani (26). The "direct" method (24) measures the plasma and total blood volume obtaining at the time of dye injection, the determination being based upon the dilution in the blood stream of a measured amount of Evans Blue of known concentration. In the "indirect" method an initial determination of blood volume is made by the "direct" method on the afternoon of the day preceding the fever treatment (Figure 1). On the morning of treatment the rate of disappearance of dye from the blood stream is determined from the dye concentration of blood serum samples taken at regular intervals over a two-hour period, and this rate is assumed to be constant throughout the ensuing experimental period. Changes in plasma volume are estimated from the deviation of the dye concentration of blood serum samples taken during fever from synchronous points on the disappearance slope, higher or lower density values representing a reduction from or increase over the prefebrile plasma volume respectively. At the end of treatment the plasma volume is again determined by the direct method, and the agreement between the final volume so determined and the final volume as estimated from the blood serum sample taken just prior to the final dye injection constitutes a check upon the accuracy with which changes in plasma volume during the fever period have been measured.

That the disappearance slope of Evans Blue does remain fairly constant during prolonged febrile periods, is evidenced by the fact that in 20 of the 31 experiments reported herein, conducted as described above, the final estimated plasma volume was within plus or minus 3 per cent of the value obtained by actual redetermination. The narrow limits within which the final check fell in 


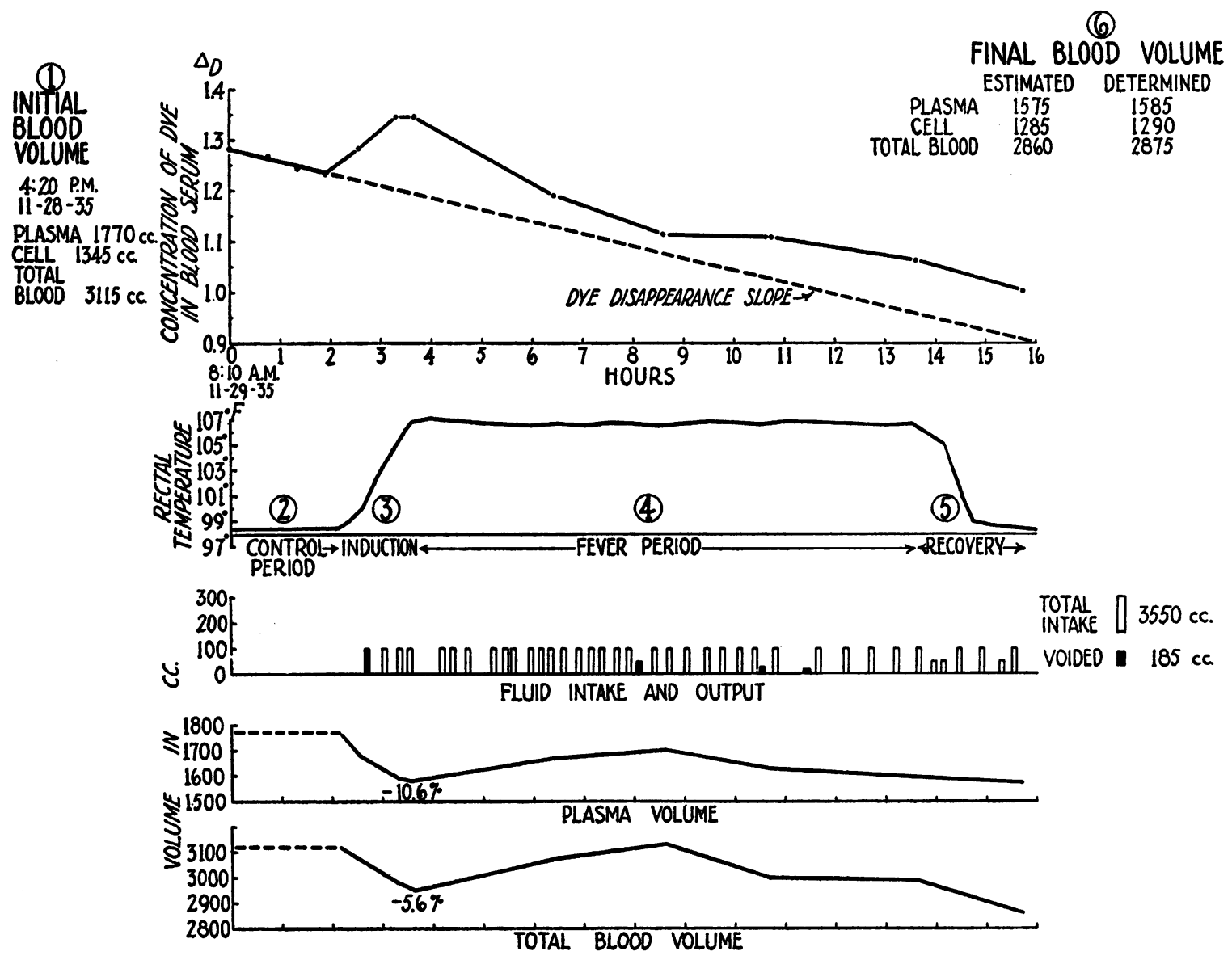

Fig. 1. Method of Determining Changes in Blood Volume during Artificial Fever

The initial blood volume (1) was determined the afternoon of the day preceding treatment. The rate of disappearance of the dye from the blood stream was determined during a prefebrile control period (2) the day of treatment. During induction of fever (3) the concentration of dye in the blood stream rose, indicating a reduction in the plasma and total blood volume. During maintenance (4) a rise and later a fall in volume which continued through recovery (5) occurred. The repeated plasma volume at the end of treatment (6) agreed well with the final estimated plasma volume.

these cases was the justification for the modified procedure followed in Cases R-2 to R-7 inclusive and D-1 to D-3 inclusive, in which the disappearance slope was not determined prior to the induction of fever. A single blood sample was taken before the patient was placed in the fever cabinet and the disappearance slope arbitrarily constructed in such a manner that the final plasma volume as estimated from the slope equalled the final redetermined plasma volume after the latter had been corrected for blood withdrawn in sampling.

We have found slight degrees of icterus to occur during artificial fever, but no colorimetric error is introduced thereby since the absorption of serum pigments at the wavelength 620 millimicrons (at which measurements of Evans Blue are made) was found to be so low that slight increases thereof were negligible in relation to the absorption due to the high concentrations of dye utilized in these plasma volume experiments.

It is our opinion that, by the methods employed, changes in plasma volume were measured to within 3 per cent. No claim for great accuracy is made for changes in red cell and total blood volume because of the differences known to exist in red cell content of peripheral and capillary blood, particularly when severe physiological disturbances are taking place.

All patients were weighed nude both before and after treatment on lever type platform scales. Weights measured in pounds were obtained to the nearest one-eighth pound, and those measured in kilograms to the nearest $0.05 \mathrm{kgm}$. Thus, changes in weight could be considered in terms of water to within about $50 \mathrm{cc}$.

Patients treated by typhoid vaccine received tap water 
by mouth, those treated by diathermy and hot moist circulating air received 0.6 per cent saline solution by mouth, or 0.85 per cent saline intravenously-patients treated by radiant energy were given tap water by mouth and in addition $\mathrm{NaCl}$ in 2 per cent solution in amounts sufficient to make the salt content of the total fluid intake approximately equal to a 0.5 per cent saline solution. Fluids given by mouth were measured in graduates and those given intravenously from the usual graduated clysis flask. It is thought that total fluid intake during each treatment was measured with an accuracy of about $50 \mathrm{cc}$. Volume of urine and vomitus was measured in graduated cylinders.

\section{ANALYTIC CONSIDERATIONS}

A bout of artificial fever may be thought of as consisting of three periods; the period of induction of temperature to the desired level during which the mechanisms of the body for temperature regulation are overcome, the period of maintenance at the desired temperature, and the period of recovery to normal temperature, during which the heat regulating mechanisms are again permitted to function successfully. Changes in plasma and total blood volume were analyzed in relation to these three periods.

It was assumed that all water lost is withdrawn directly from the blood stream via the skin, lungs, or kidneys, that weight changes may be considered in terms of water and that weight change represents the true difference between the gross water loss from the blood stream and total fluid intake, according to the equation

$$
\begin{aligned}
\text { Gross Water Loss }=\text { Total Fluid Intake }+ \\
\text { Weight Loss or - Weight Gain }
\end{aligned}
$$

The amount of fluid withdrawn from tissue spaces in patients inadequately supplied with water or the amount entering the tissue spaces in those in whom excessive fluids were given was calculated by the equation ing the short treatments to $500 \mathrm{cc}$. during the long treatments could not be included in total fluid intake. On the other hand, it was not possible to determine, except in those cases in which all fluids were given intravenously, that all fluids administered were completely absorbed by the end of the experimental period. These two sources of error tend to compensate each other. It is felt that gross water loss and tissue fluid changes calculated in the above manner are valid to within about 5 per cent, and are of value for the clinical interpretation of the signs and symptoms presented during artificial fever.

\section{MATERIAL STUDIED}

Thirty-one studies were carried out on 25 patients, 21 of whom were males and 4 females. All were undergoing fever therapy, the diagnoses being indicated in Table III. In 3 studies, fever was induced by the intravenous injection of killed typhoid organisms. In 8 studies diathermy was used, the apparatus employed being the "Super Power" unit, with segmented electrodes encircling the arms, thighs, and waist, the current varying from 1500 to 2600 milliamperes. In one case treated with typhoid vaccine and in two cases treated by diathermy additional heating in the form of radiant energy (carbon filament lamp) was used. In 13 studies, 3 of which were made at Dayton, Ohio, fever was induced by hot moist circulating air in the "Kettering Hypertherm" (27). In the 10 studies made in Boston the relative humidity in the cabinet was maintained between 30 and 50 per cent during induction of fever. Dry bulb temperature was about 155 to $160^{\circ} \mathrm{F}$. and the wet bulb about 130 to $135^{\circ} \mathrm{F}$. during induction. During maintenance, the air current was turned off and the patient was covered with blankets. In the 3 cases studied in Dayton, relative humidity was about 80 per cent, dry bulb and wet bulb temperatures being about $130^{\circ} \mathrm{F}$. and $125^{\circ} \mathrm{F}$. during induction, and $125^{\circ} \mathrm{F}$. and $120^{\circ} \mathrm{F}$. during maintenance respectively. Air speeds were somewhat

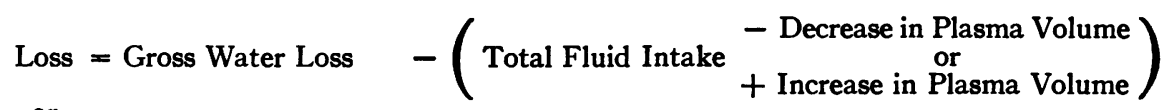

$$
\begin{aligned}
& \text { Tissue Fluid or } \\
& \text { Gain }=\left(\begin{array}{c}
\text { Total Fluid Intake }- \text { Decrease in Plasma Volume } \\
\text { or Increase in Plasma Volume }
\end{array}\right)-\text { Gross Water Loss }
\end{aligned}
$$

In cases in which vomiting occurred the amount of vomitus was deducted from total fluid intake as being fluid not available for replacement of water losses. Because of the difficulty of determining the amount of urine in the bladder at the beginning and end of treatment, data on urinary output are not regarded as more than approximations. For comparison of individuals, changes in gross water loss and tissue fluid were considered in terms of cc. per hour per kgm. of body weight.

These equations are intended to give only approximate measurements of the changes in the water balance. Oxygen consumption was not measured and therefore the water of oxidation which might range from $200 \mathrm{cc}$. dur- slower and the total air space somewhat smaller in the cabinets used in Dayton than in those used in Boston. Induction to desired fever levels was slower with the low than with the high humidities. In 7 studies conducted at Rochester, N. Y., fever was induced by means of radiant energy (carbon filament lamps) in cabinets with limited static air space (28).

Rectal-temperature was elevated to 103 to $104^{\circ} \mathrm{F}$. in the patients treated with typhoid vaccine, and to $106^{\circ} \mathrm{F}$. or over in most of the patients treated by the physical modalities. Treatment was discontinued because of collapse in Cases 4 and 17, treated by diathermy, and in Cases 2, 10, and 21 treated by hot moist circulating air. 
TABLE I

Blood volume changes in fever produced by intravenous injection of killed typhoid organisms

\begin{tabular}{|c|c|c|c|c|c|c|c|}
\hline \multirow{2}{*}{$\begin{array}{l}\text { Date } \\
\text { and } \\
\text { time }\end{array}$} & \multirow{2}{*}{$\begin{array}{l}\text { Rec- } \\
\text { tal } \\
\text { tem- } \\
\text { pera- } \\
\text { ture }\end{array}$} & \multicolumn{3}{|c|}{$\begin{array}{c}\text { Blood } \\
\text { volume }\end{array}$} & \multicolumn{2}{|c|}{$\begin{array}{l}\text { Change in } \\
\text { volume }\end{array}$} & \multirow{2}{*}{ Clinical notes } \\
\hline & & Plasma & Cell & $\begin{array}{l}\text { To- } \\
\text { tal } \\
\text { blood }\end{array}$ & Plasma & $\begin{array}{c}10- \\
\text { tal } \\
\text { blood }\end{array}$ & \\
\hline & ${ }^{\circ} \mathrm{F}$. & $c c$. & $c c$ & cc. & $\begin{array}{l}\text { per } \\
\text { cent }\end{array}$ & $\begin{array}{l}\text { per } \\
\text { cent }\end{array}$ & \\
\hline
\end{tabular}

CASE II. MALE AGED 44

\begin{tabular}{|c|c|c|c|c|c|c|c|}
\hline $\begin{array}{c}\text { Apr. } 1,1936 \\
4: 45 \text { p.m. }\end{array}$ & 99.0 & 2135 & 1475 & 3160 & & & Basal volume \\
\hline $\begin{array}{c}\text { Apr. } 2,1936 \\
\text { 10:07 a.m. }\end{array}$ & 99.2 & & & & & & $\begin{array}{l}125 \text { million killed ty- } \\
\text { phoid organisms in- } \\
\text { travenously }\end{array}$ \\
\hline 10:42 a.m. & 99.4 & 2035 & 1440 & 3475 & -4.7 & -3.7 & \\
\hline 11:26 a.m. & 99.4 & 2175 & 1490 & 3665 & +1.9 & +1.5 & Mild chill \\
\hline 12:54 p.m. & 100.0 & 2135 & 1525 & 3660 & 0 & +1.4 & $\begin{array}{l}65 \text { million killed ty- } \\
\text { phoid organisms } \\
\text { given intravenously }\end{array}$ \\
\hline 2:15 p.m. & 100.5 & 2095 & 1515 & 3610 & -1.9 & 0 & $\begin{array}{l}100 \text { million killed ty- } \\
\text { phoid organisms in- } \\
\text { travenously }\end{array}$ \\
\hline 3:16 p.m. & 100.8 & 1955 & 1530 & 3610 & -3.8 & 0 & $\begin{array}{l}\text { Severe chill } 3: 10 \text { to } \\
3: 40 \text { p.m. }\end{array}$ \\
\hline 3:30 p.m. & 102.0 & 2010 & 1620 & 3630 & -1.2 & +0.6 & \\
\hline 3:53 p.m. & 103.2 & 2140 & 1600 & 3740 & +0.2 & +3.6 & \\
\hline 5:30 p.m. & 102.0 & 2080 & 1450 & 3530 & -2.6 & -2.2 & Repeated final volume \\
\hline
\end{tabular}

CASE I6. MALR AQED 3 I

\begin{tabular}{|c|c|c|c|c|c|c|c|}
\hline $\begin{array}{c}\text { May 27, } 1936 \\
\text { 4:33 p.m. }\end{array}$ & 99.0 & 3230 & 2340 & 5570 & & & Basal volume \\
\hline $\begin{array}{c}\text { May 28, } 1936 \\
\text { 9:50 a.m. }\end{array}$ & 99.0 & & & & & & $\begin{array}{l}150 \text { million killed ty- } \\
\text { phoid organisms in- } \\
\text { travenously }\end{array}$ \\
\hline 11:37 a.m. & 99.4 & 3185 & 2925 & 6110 & -1.7 & +9.7 & Mild chill at 11:23 a.m. \\
\hline 1:47 p.m. & 101.4 & 3230 & 2740 & 5970 & 0 & +7.2 & $\begin{array}{l}100 \text { million killed ty- } \\
\text { phoid organisms in- } \\
\text { travenously }\end{array}$ \\
\hline 3:57 p.m. & 102.6 & 3140 & 2720 & 5860 & -2.8 & +5.2 & \\
\hline $\begin{array}{l}\text { 4:05 to } \\
\text { 5:27 p.m. }\end{array}$ & & & & & & & $\begin{array}{l}\text { Exposed to carbon fila- } \\
\text { ment lampsin cablnet }\end{array}$ \\
\hline 4:52 p.m. & 103.3 & 3095 & 2455 & 5550 & -4.5 & -0.3 & Profuse perspiration \\
\hline 5:28 p.m. & 103.4 & 3020 & 2570 & 5590 & -6.5 & +0.3 & \\
\hline 6:51 p.m. & 101.4 & 2890 & 2340 & 5230 & -10.5 & -5.9 & Repeated final volume \\
\hline
\end{tabular}

CABE 9. MALE AGED $3 I$

\begin{tabular}{|c|c|c|c|c|c|c|c|}
\hline $\begin{array}{c}\text { Jan. 19, } 1937 \\
9: 39 \text { a.m. }\end{array}$ & 98.8 & 3280 & 1700 & 4980 & & & Basal volume \\
\hline 10:15 a.m. & & & & & & & $\begin{array}{l}150 \text { million killed ty- } \\
\text { phoid organisms in- } \\
\text { travenously }\end{array}$ \\
\hline 1:09 p.m. & 100.6 & & & & & & $\begin{array}{l}150 \text { million killed ty- } \\
\text { phoid organisms in- } \\
\text { travenously }\end{array}$ \\
\hline $\begin{array}{l}\text { 1:58 to } \\
\text { 2:23 p.m. }\end{array}$ & 101.0 & & & & & & Severe chill \\
\hline 2:48 p.m. & 105.4 & 3350 & 1870 & 5220 & +2.1 & +4.8 & Repeated volume \\
\hline 5:52 p.m. & 101.8 & 3240 & 1870 & 5110 & -1.2 & +2.6 & Repeated final volume \\
\hline
\end{tabular}

Reactions of varying severity were encountered in a few cases as noted in Table II but treatment was uneventful in the other cases.

\section{RESULTS}

The height and duration of fever, and the changes in plasma and total blood volume, expressed in terms of percentage deviation from prefebrile levels, during induction and maintenance of and recovery from fever, together with the fluid intake for each period are shown in Table II. Weight changes, urinary volume, gross water loss, and tissue fluid changes are shown in Table III.

\section{Changes in plasma volume}

Very little change from prefebrile plasma volume occurred in patients in whom fever was induced by typhoid vaccine, a decrease of 4.5 per cent and an increase of 0.2 per cent having been observed at the height of fever $\left(103.2^{\circ} \mathrm{F}\right.$.) in Cases 11 and 16 respectively and an increase of 2.1 per cent (at $105.4^{\circ} \mathrm{F}$.) in Case 9. (See Table I.) During the fall in temperature, reductions of 2.6 per cent and 1.2 per cent were noted in Cases 11 and 9 respectively. In Case 16, exposed to the heat of carbon filament lamps when the rectal temperature was $102.6^{\circ} \mathrm{F}$. a prompt and considerable decrease in plasma volume took place and continued during recovery, final plasma volume being reduced 10.5 per cent.

During the induction of fever by diathermy, which required an average time of one hour and forty minutes, reductions in plasma volume were observed in all cases, ranging from 6.6 per cent (Case 12) to 19.8 per cent (Case 17) (Table II). During the maintenance of fever, plasma volume fell to lower levels than those obtaining at the end of induction in all cases, reductions ranging from 8.6 per cent (Case 12) to 32.0 per cent (Case 17). In the latter case, and in Case 4, in whom plasma volume was reduced 15.9 per cent, treatment was discontinued after temperature had been maintained at $104^{\circ} \mathrm{F}$. for one hour because of the development of peripheral vascular collapse. At the end of recovery, plasma volume was even lower than during the maintenance period in Cases 4, 25, and 19, and slightly higher in Cases $12,14,17$, and 23 , but in no case had it returned to the prefebrile level. 
During the induction of fever in the "Kettering Hypertherm " which required an average time of a little over two hours, plasma volume was reduced in all cases, except in Cases 6 and 13 in whom fluids were given intravenously. The most severe reductions were encountered in Cases 2, 10 , and 21 , amounting to $19.5,26.9$, and 16.8 per cent respectively, and treatment was discontinued in these cases shortly after induction. In cases in whom fluids were given intravenously during maintenance $(2,6,10,13,20$, and D-3) plasma volume rose above levels obtaining at the end of induction of fever, and in cases given fluids by mouth $(8,18,24,26, \mathrm{D}-1$, and $\mathrm{D}-2)$ remained at or fell slightly below the level obtaining at the end of induction. During recovery to normal temperature, plasma volume tended to diminish in those cases in whom it had been raised above normal by the intravenous administration of fluids and to increase in those cases given fluids by mouth, but returned to the prefebrile level only in Cases 6,13 , and $\mathrm{D}-3$, to whom fluids were given by vein and in Cases 8 and 18, given fluid by mouth.

Induction of fever required an average of one hour and fifty minutes in the radiant energy cabinet and was accompanied by a reduction in plasma volume in all cases ranging from 5.9 per cent (Case R-5) to 17.0 per cent (Case R-6). Except in Case $\mathrm{R}-5$, plasma volume rose above the level reached at the end of induction during maintenance of fever and in Cases R-4 and R-5 rose above the prefebrile level. During the return to normal temperature, plasma volume fell, reaching levels equal to or slightly below those obtaining at the end of induction of fever, except in Case $\mathrm{R}-4$ in whom it was slightly higher.

\section{Changes in total blood volume}

Total blood volume was increased in the three patients treated with typhoid vaccine as a result of an influx of red cells into the circulation during the febrile period in amounts large enough to offset the slight reductions that occurred in plasma volume.

In general, changes in total blood volume tended to parallel the changes in plasma volume during induction of fever in the patients treated by the physical modalities. Increases in the red cells, during maintenance of fever large enough to in- crease total blood volume above prefebrile level in spite of a diminished plasma volume, were observed in Case 12, treated with diathermy, Case 2 treated with the "Kettering Hypertherm," and in Case R-1 treated with radiant energy. After recovery to normal temperature, total blood volume was below the prefebrile level in all cases, except in Cases 6, 13, and 18 of whom the first two received all fluids by vein.

\section{Changes in water balance-gross water loss}

Gross water loss averaged $510 \mathrm{cc}$, or $1.0 \mathrm{cc}$. per $\mathrm{kgm}$. per hour in the three cases treated with typhoid vaccine (Table III). The losses in the cases treated by the physical modalities were far greater, averaging 8.0, 9.1, and $6.4 \mathrm{cc}$. per $\mathrm{kgm}$. per hour in the groups treated by diathermy, hot moist circulating air, and radiant energy respectively.

Within each group there were some individual variations in relation to the duration of fever and rate of fluid intake, and the route by which fluids were given. In none of these cases who received fluids by mouth was the rate of gross fluid loss proportional either to the number of hours of treatment, or to the rate of fluid intake. Several cases treated by hot moist circulating air received fluids by vein and here again it is evident that the rate of gross water loss is not increased by prolongation of fever, nor decreased by a high rate of fluid administration (compare Cases 6, 8 and 26, Table III).

\section{Tissue fluid loss}

In cases treated by typhoid vaccine, tissue fluid changes were within the limit of experimental error, but were of considerable magnitude in the cases treated by the physical agencies. All the patients treated by diathermy and radiant energy experienced losses in tissue fluid, the rate of loss being in general inversely related to the rate of fluid intake. Six of the cases treated in the "Kettering Hypertherm" experienced increases in tissue fluid, two of them having received fluid by vein and the others by mouth, but all at rates higher than received by any of the cases in the other two groups. The other seven cases suffered losses in tissue fluid, the rate of loss being inversely related to the rate of fluid intake. 

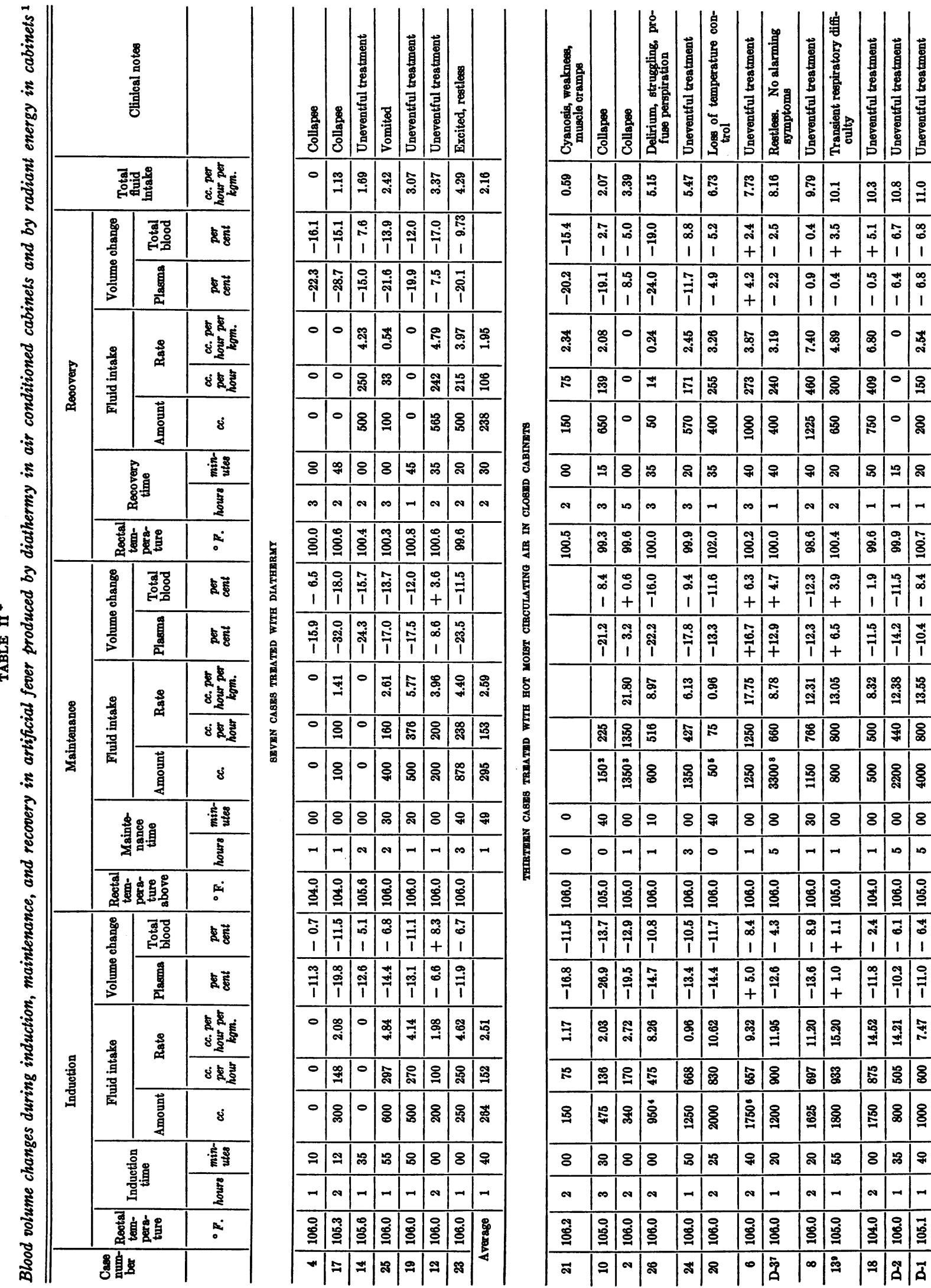

旁

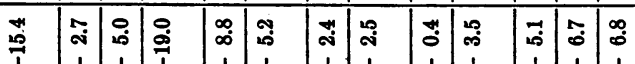

สิ่

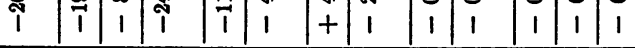

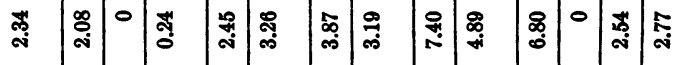

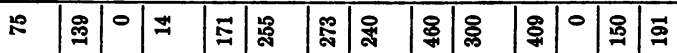

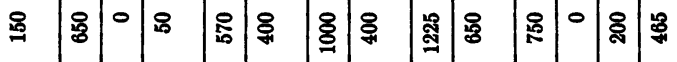

8 10/8

๙

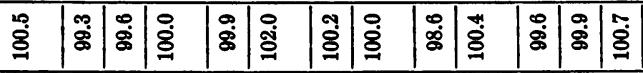

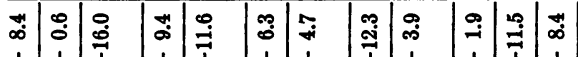

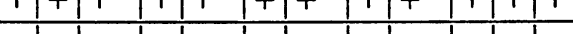

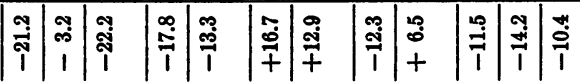

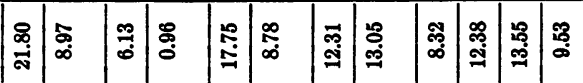

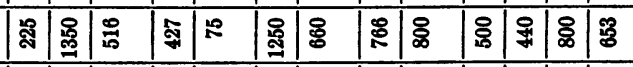

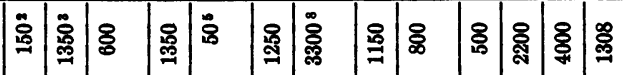

-

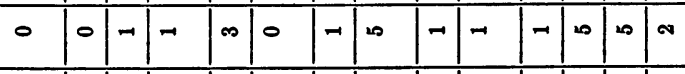

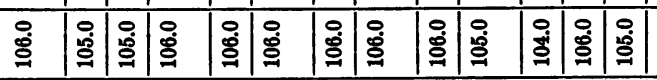

㽞

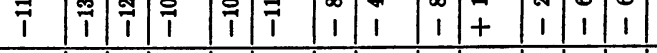

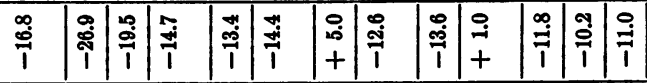

Э

¿

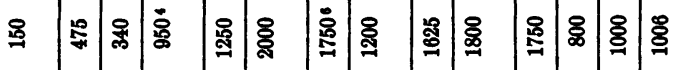

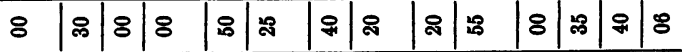

๙

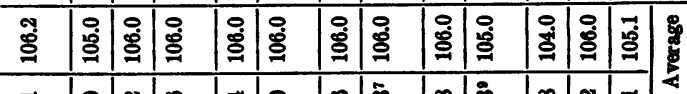

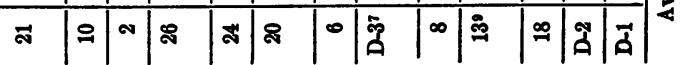


PHYSIOLOGY OF ARTIFICIAL FEVER
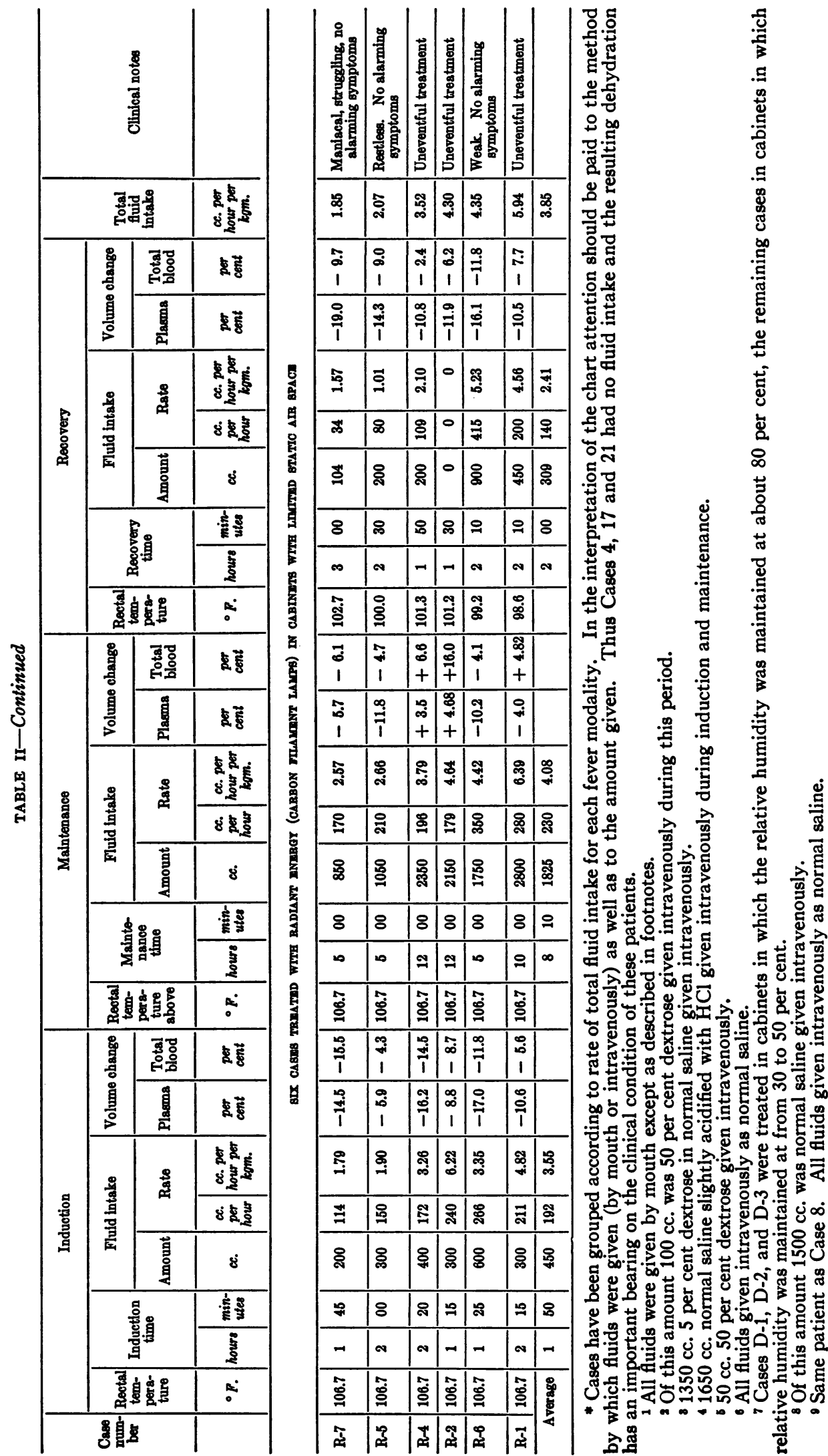
TABLE III

Gross water loss and changes in tissue fluid in fever induced by diathermy, in air conditioned cabinets, and by radiant energy in cabinets

\begin{tabular}{|c|c|c|c|c|c|c|c|c|c|c|c|c|c|c|c|c|}
\hline \multirow{2}{*}{$\begin{array}{l}\text { Case } \\
\text { num- } \\
\text { ber }\end{array}$} & \multirow{2}{*}{ Date } & \multirow{2}{*}{$\begin{array}{l}\text { Age } \\
\text { years }\end{array}$} & \multirow{2}{*}{ Sex } & Diagnosis & Weight & \multicolumn{2}{|c|}{$\begin{array}{c}\text { Duration } \\
\text { of } \\
\text { treatment }\end{array}$} & \multicolumn{2}{|c|}{$\begin{array}{c}\text { Total fluid } \\
\text { intake } 1\end{array}$} & $\begin{array}{l}\text { Weight } \\
\text { change } \\
\text { at end } \\
\text { of treat- } \\
\text { ment }\end{array}$ & \multicolumn{2}{|c|}{$\begin{array}{c}\text { Gross water } \\
\text { loss } 2\end{array}$} & $\begin{array}{l}\text { Fluid } \\
\text { lost } \\
\text { as } \\
\text { urine }\end{array}$ & \multicolumn{2}{|c|}{$\begin{array}{c}\text { Tissue fluid } \\
\text { changes }^{3}\end{array}$} & Clinical notes \\
\hline & & & & & kgm. & hours & $\begin{array}{l}\min - \\
\text { utes }\end{array}$ & $c c$. & $\begin{array}{c}c c . \text { per } \\
\text { hour } \\
\text { per } \\
\text { kgm. }\end{array}$ & grams & cc. & $\begin{array}{l}\text { cc. per } \\
\text { hour } \\
\text { per } \\
\text { kgm. }\end{array}$ & cc. & $c c$. & $\begin{array}{c}\text { cc. per } \\
\text { hour } \\
\text { per } \\
\text { kgm. }\end{array}$ & \\
\hline
\end{tabular}

THREI CASES TREATED BY KILLED TYPHOID ORGANISMS GIVEN INTRA VENOUSLY

\begin{tabular}{|c|c|c|c|c|c|c|c|c|c|c|c|c|c|c|c|c|}
\hline 11 & Apr. 2,1936 & 44 & $\mathbf{M}$ & Paresis & 43.3 & 8 & 15 & 75 & 0.2 & -400 & 475 & 1.3 & 0 & -155 & -0.4 & \\
\hline 16 & May 28,1936 & 31 & $\mathbf{M}$ & Paresis & 63.3 & 9 & 15 & 500 & 0.9 & -600 & 580 & 1.0 & 125 & -420 & -0.7 & $\begin{array}{l}\text { Exposed to heat of carbon fila- } \\
\text { ment lamps }\end{array}$ \\
\hline 9 & Jan. 19,1936 & 31 & $\mathbf{M}$ & Paresis & 57.5 & 7 & 45 & 675 & 1.5 & +200 & 475 & 1.0 & 350 & +160 & +0.4 & \\
\hline & verage & & & & & & & 416 & 0.9 & & 510 & 1.0 & & -138 & -0.3 & \\
\hline
\end{tabular}

WIGHT CABES TREATED BY DIATHERMY

\begin{tabular}{|c|c|c|c|c|c|c|c|c|c|c|c|c|c|c|c|c|}
\hline 4 & Jan. 30,1936 & 39 & $\mathbf{M}$ & Paresis & 54.3 & 5 & 00 & 0 & 0 & -3300 & 3300 & 12.2 & 0 & -2770 & -10.2 & Collapsed \\
\hline 17 & July 2,1936 & 44 & M & Paresis & 71.2 & 5 & 00 & 400 & 1.1 & -2840 & 3240 & 6.5 & 0 & -1970 & -5.5 & Collapsed \\
\hline 15 & May 8,1936 & 37 & $\mathbf{M}$ & Paresis & 59.3 & 6 & 40 & 500 & 1.3 & -2600 & 2300 & 4.1 & 0 & -1410 & -3.6 & \\
\hline 14 & Apr. 22,1936 & 37 & $\mathbf{M}$ & Paresis & 59.2 & 5 & 00 & 500 & 1.7 & -1400 & 1900 & 6.4 & 0 & -970 & -3.3 & \\
\hline 25 & Feb. 2,1937 & 45 & $\mathbf{M}$ & Paresis & 61.3 & 6 & 45 & 1000 & 2.4 & -2850 & 3850 & 9.3 & 0 & -2260 & -5.5 & Delirium, mania \\
\hline 19 & July 23,1936 & 51 & $\mathbf{M}$ & Paresis & 65.2 & 5 & 00 & 1000 & 3.0 & -2100 & 3100 & 9.5 & 0 & -1605 & -4.9 & $\begin{array}{l}\text { Exposed to heat of carbon fila- } \\
\text { ment lamps }\end{array}$ \\
\hline 12 & Apr. 9,1936 & 42 & $\mathbf{M}$ & Paresis & 50.5 & 5 & 40 & 965 & 3.3 & -1050 & 2015 & 7.1 & 0 & -490 & -1.7 & \\
\hline 23 & Jan. 13, 1937 & 28 & $\mathbf{M}$ & Paresis & 54.1 & 7 & 00 & 1625 & 4.3 & -1900 & 3525 & 9.4 & $?$ & -1360 & -3.7 & $\begin{array}{l}\text { Exposed to heat of carbon fila- } \\
\text { ment lamps }\end{array}$ \\
\hline & Average & & & & & & & 749 & 2.2 & & 2900 & 8.1 & & -1604 & -4.5 & \\
\hline
\end{tabular}

THIRTER CASTS TREATTED WTTH HOT MOIST CIRCULATTNG AIR IN CLOSED CABINETS

\begin{tabular}{|c|c|c|c|c|c|c|c|c|c|c|c|c|c|c|c|c|}
\hline 21 & July 8,1936 & 50 & $\mathbf{M}$ & Paresis & 64.2 & 4 & 00 & 150 & 0.6 & -2300 & 2450 & 9.6 & 0 & -2340 & -9.1 & Collapsed \\
\hline 10 & Mar. 26, 1936 & 45 & $\mathbf{M}$ & Paresis & 66.8 & 7 & 25 & 1275 & 2.0 & -1935 & 4775 & 9.7 & 0 & -2840 & -5.7 & $\begin{array}{l}\text { Collapsed. Recovery after } 100 \\
\text { cc. } 50 \text { per cent dextrose given } \\
\text { intravenously }\end{array}$ \\
\hline 2 & Dec. 13, 1935 & 45 & $\mathbf{M}$ & Paresis & 62.5 & 8 & 00 & 1690 & 3.4 & -2800 & 4490 & 8.9 & 0 & -2560 & -5.1 & $\begin{array}{l}\text { Collapsed. Recovery on } 1350 \text { cc. } \\
\text { 5per cent dextroseintravenously }\end{array}$ \\
\hline 26 & Mar. 5, 1937 & 36 & $\mathbf{M}$ & Paresis & 57.5 & 5 & 45 & 1700 & 5.2 & -2900 & 4600 & 13.9 & 0 & -2250 & -6.8 & $\begin{array}{l}\text { Delirium, mania. } 1650 \mathrm{cc} \text {. normal } \\
\text { saline given intravenously }\end{array}$ \\
\hline 24 & Feb. 18,1937 & 50 & $\mathbf{M}$ & Paresis & 69.7 & 8 & 20 & 3170 & 5.5 & -1500 & 4670 & 8.1 & 0 & -1130 & -1.9 & \\
\hline 20 & July 31, 1936 & 44 & $\mathbf{M}$ & Paresis & 78.1 & 4 & 40 & 2450 & 6.7 & -700 & 3150 & 8.1 & 0 & -540 & -1.5 & $\begin{array}{l}50 \text { cc. of } 50 \text { per cent dextrose } \\
\text { intravenously }\end{array}$ \\
\hline 6 & Feb. 20,1936 & 28 & $\mathbf{M}$ & Paresis & 70.5 & 7 & 20 & 4000 & 7.7 & +1200 & 2800 & 5.4 & 540 & +1310 & +2.5 & All fluids given intravenously \\
\hline D-3 & July 23,1937 & 26 & $\mathbf{M}$ & $\begin{array}{l}\text { Primary } \\
\text { syphilis }\end{array}$ & 75.1 & 8 & 00 & 4900 & 8.2 & -600 & 5500 & 9.2 & 0 & -525 & -0.9 & 1500 cc. given intravenously \\
\hline 8 & Mar. 12, 1936 & 43 & $\mathbf{M}$ & Paresis & 62.2 & 6 & 30 & 4000 & 9.8 & +2000 & 2000 & 4.9 & 0 & +2020 & +5.0 & $\begin{array}{l}\text { Same patient as Case 13. All } \\
\text { fluids given by mouth }\end{array}$ \\
\hline 13 & Apr. 16, 1936 & 43 & $\mathbf{M}$ & Paresis & 61.3 & 5 & 15 & 3250 & 10.1 & +1300 & 1950 & 6.1 & 175 & +1290 & +4.2 & $\begin{array}{l}\text { Same patient as Case 8. All } \\
\text { fluids given intravenously }\end{array}$ \\
\hline 18 & July 9,1936 & 57 & $\mathbf{M}$ & Paresis & 60.2 & 4 & 50 & 3000 & 10.3 & +400 & 2600 & 8.9 & 250 & +385 & +1.3 & \\
\hline D-2 & July 22,1937 & 37 & $\mathbf{F}$ & Paresis & 59.0 & 8 & 00 & 5200 & 11.0 & +700 & 4500 & 9.5 & 90 & +460 & +0.9 & \\
\hline D-1 & July 22,1937 & 32 & $\mathbf{M}$ & $\begin{array}{l}\text { Undulant } \\
\text { fever }\end{array}$ & 35.6 & 7 & 50 & 3000 & 10.8 & +1250 & 1750 & 6.3 & 0 & +1130 & +4.1 & \\
\hline & Average & & & & & & & 2906 & 7.0 & & 3484 & 9.1 & & -438 & -1.0 & \\
\hline
\end{tabular}


TABLE III-Continued

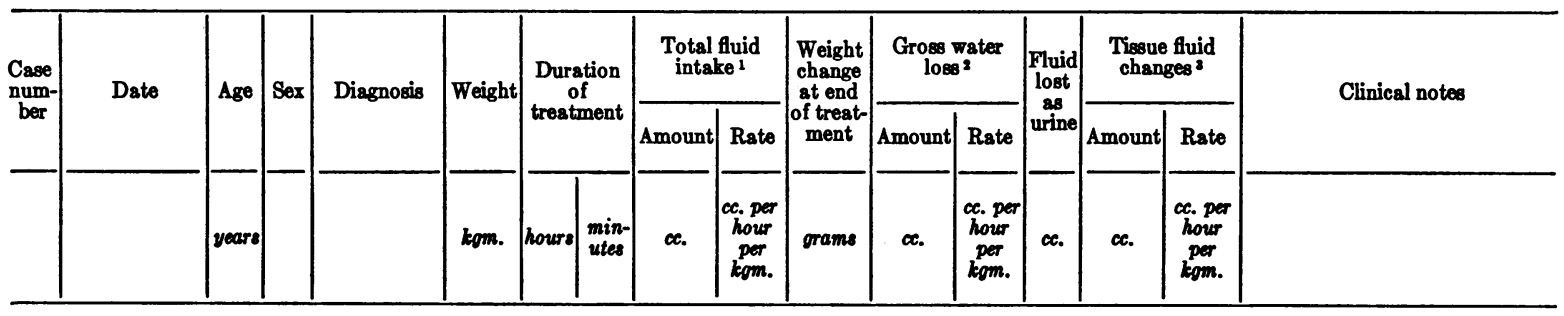

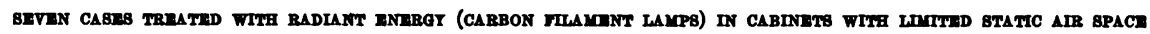

\begin{tabular}{|c|c|c|c|c|c|c|c|c|c|c|c|c|c|c|c|c|}
\hline R-7 & July 16,1937 & 42 & $\mathbf{M}$ & Paresis & 63.7 & 9 & 45 & 1150 & 1.9 & -2300 & 3450 & 5.7 & $?$ & -1755 & -2.8 & Incontinent of urine \\
\hline R-5 & July 7,1937 & 37 & $\mathbf{F}$ & Paresis & 79.0 & 9 & 30 & 1550 & 2.0 & -1600 & 3150 & 4.2 & $?$ & -1160 & -1.6 & Incontinent of urine \\
\hline $\mathbf{R}-\mathbf{4}$ & June 30, 1937 & 42 & $\mathbf{M}$ & Paresis & 51.8 & 16 & 10 & 2950 & 3.5 & -1400 & 4350 & 5.2 & 965 & -1135 & -1.4 & \\
\hline R-2 & June 23, 1937 & 38 & $\mathbf{F}$ & $\begin{array}{l}\text { Tabo- } \\
\text { paresis }\end{array}$ & 38.6 & 14 & 45 & 2450 & 4.3 & -1500 & 3950 & 6.8 & 2550 & -1250 & -2.2 & $\begin{array}{l}\text { Cord bladder. Retention with } \\
\text { incontinence }\end{array}$ \\
\hline R-6 & July 15,1937 & 34 & $\mathbf{M}$ & $\begin{array}{c}\text { Multiple } \\
\text { myeloma }\end{array}$ & 79.4 & $\boldsymbol{\theta}$ & 25 & 3250 & 4.4 & -2600 & 5850 & 7.8 & 300 & -2080 & -2.8 & Received x-ray therapy at $106^{\circ} \mathrm{F}$. \\
\hline R-3 & June 24, 1937 & 34 & $\mathbf{M}$ & $\begin{array}{l}\text { Acute non- } \\
\text { specifio } \\
\text { arthritis }\end{array}$ & 69.6 & 8 & 12 & 2800 & 4.9 & -1160 & 3960 & 6.9 & 675 & -860 & -1.5 & \\
\hline R-1 & Nov. 29, 1936 & 20 & $\mathbf{F}$ & Gonorrhea & 43.8 & 13 & 40 & 3550 & 5.9 & -1100 & 4650 & 7.8 & 110 & -915 & -1.5 & \\
\hline & verage & & & & & & & 2530 & 3.9 & & 4194 & 6.4 & & -1307 & -1.8 & \\
\hline
\end{tabular}

1 All fluids given by mouth except as noted.

2 Computed from Equation (1) above.

${ }^{3}$ Computed from Equation (2) above.

\section{DISCUSSION}

The data presented in this study cover an admittedly wide range of experimental conditions. The condition of the patients' cardiovascular and neurological systems varied greatly, as did their mental and emotional states. In each group treated by the same physical agency, the height and duration of fever, and the amount, rate of, and mode of fluid administration purposely were varied to observe the effects of dehydration and overhydration. The physical modalities of fever used each imposed a different set of environmental conditions and it is evident that individuals varied greatly in their response to comparable bouts of fever and fluid intake levels. However, certain general trends were observed on the basis of which conclusions as to the physiological effects of artificially induced fever can be drawn justifiably.

In the three subjects treated by typhoid vaccine the observed changes in blood volume and in the water balance were of no clincal significance. It is true that the fever was of less degree and duration than in any of the patients in the other groups and this may account to some extent for the great differences in blood volume changes, and gross water and tissue fluid losses observed between the patients treated with vaccine and by physical means. However, patients in the former group sweat very little, experienced little thirst, and showed little vasodilatation. In contrast, the patients in the latter group showed pronounced vasodilatation and sweating, and it is therefore evident that the contrasting situation as regards blood volume and water balance changes is not a result of the differences in temperature levels alone.

One of the major physiological effects of fever artificially induced by physical means is a diminution in circulating blood volume. This diminution is owing to the uncompensated loss of large quantities of water from the blood stream, resulting in a reduction in the plasma portion of the blood and in hemoconcentration. The latter effect is slightly augmented by small increases in the number of circulating red cells, never great enough to equal the loss of plasma. The degree of reduction in plasma volume is determined by the difference in rate of outflow by skin, lung, and kidneys and of effective absorption of fluids administered. If insufficient fluids are given, the 
tissue fluids of the body are drawn upon for the maintenance of plasma volume with resultant dehydration. Blood volume may be maintained at prefebrile levels by intravenous administration of fluids, but in only 2 cases in this series was it maintained at prefebrile level when fluids were given by mouth even in large amounts. Too rapid administration of fluids by vein may result in an excessive increase in blood volume and result in cardiac embarrassment and failure.

Gross water loss occurs most rapidly during the induction of fever. In all cases in this series receiving fluids by mouth, a reduction in plasma volume took place during induction, the percentage reduction from prefebrile levels being inversely related to the rate of fluid administration, and directly related to the time required for elevation of temperature. It is evident from the data presented in Figure 2 that an induction time longer than 2 hours, by and large, involves the risk of reduction in plasma volume to critical levels.

There are some differences in the degree of reduction in blood volume that can be borne by individual patients at high temperatures. It is, however, evident that for each individual there is a definite limit beyond which further loss of fuid from the blood stream cannot be tolerated. In those patients who experienced collapse, characterized by cyanosis, tachycardia with weak, thready pulse, marked fall in systolic blood pressure, respiratory difficulty, and even coma, total blood volume was severely diminished at the time collapse occurred. As these patients recovered, total blood volume tended to rise in proportion to the amount of fluid given during recovery. In those in whom fluids were restricted during recovery the total blood volume remained reduced but cir-

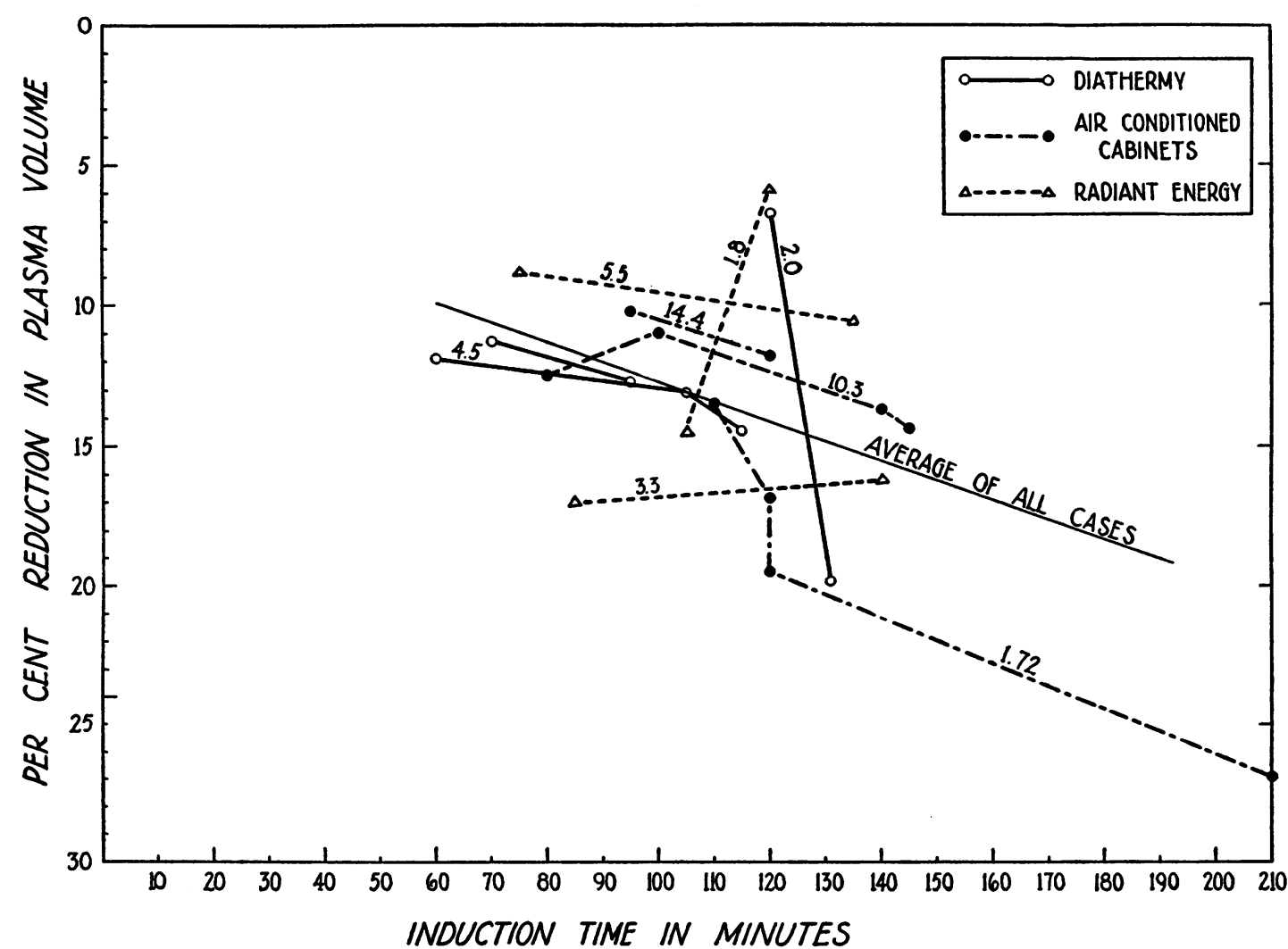

Fig. 2. Relationship of Percentage Reduction in Plasma Volume to the Time Required for Fever Induction. All Cases Received Fluids by Mouth

Cases have been grouped according to rate of fluid intake for each physical modality, the numerals above the connecting lines indicating the average intake in cubic centimeters per hour per kgm. The percentage reduction in plasma volume increases as the induction time is prolonged. 
culatory readjustment took place at the reduced level as the temperature fell to normal. Thus, shock resulting from severe diminution in circulating blood volume is a potential danger in every patient treated with artificial fever. Its prevention depends primarily upon adequate maintenance of the volume of the circulating blood.

In Cases 8 and 13 (Tables II and III) the same patient was subjected to bouts of fever of comparable height and duration. In the former instance all fluids were given by the intravenous route, and blood volume was well maintained throughout treatment. In the latter instance all fluids were given by mouth at about an equal rate, but a moderately severe reduction in plasma and total blood volume occurred during induction and maintenance of fever, even though the gain in weight and the rate of gross water loss were nearly equal in both experiments. It is evident that water may pass out of the blood stream more rapidly than it can be absorbed from the intestinal tract, and this fact has an important bearing on the determination of the optimal rate of fluid administration for maintenance of blood volume.

From the data presented in Table II it is evident that the fluid requirement varies with the apparatus employed. Thus, the average rate of fluid intake necessary to maintain plasma volume level and water balance is about 8,9 , and $6 \mathrm{cc}$. per hour per $\mathrm{kgm}$. for diathermy, the "Kettering Hypertherm," and radiant energy (28) respectively. If an uncooperative or irrational patient fails to take the prescribed amount of water by mouth by the end of fever induction, it may be necessary to give fluid parenterally to maintain the water balance.

The mental state of the patient has an important relation to gross water loss and hence fluid requirement as evidenced by the diminution in blood volume and by the gross water and tissue fluid losses in Cases 26, D-3, and R-7. These patients were noisy, restless, or maniacal, took fluids less readily and tolerated treatment less well than those who were quiet and cooperative.

From the data presented in Figure 3 it is evident that the prolongation of temperature at high levels does not entail a progressively increasing rate of gross water loss. There is no relation between the amount of gross water loss and the amount, or rate, or route of administration of fluid as illustrated in Figure 4. Gross water loss is determined principally by the temperature and to some extent by the relative humidity of the patient's immediate environment. The water loss was greatest in those cases in whom the differ-

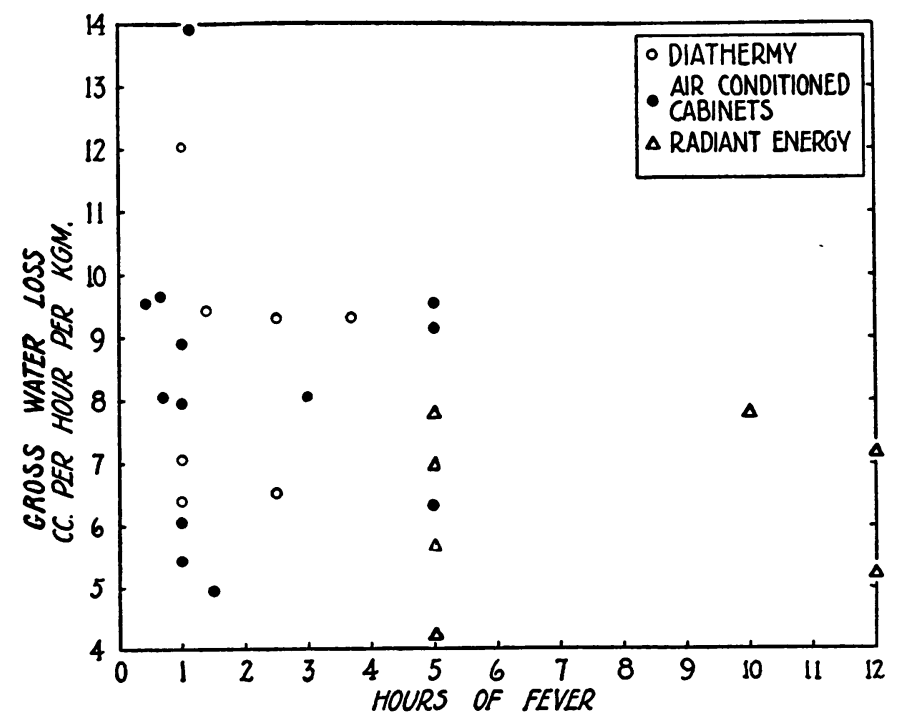

Fig. 3. Relationship of Gross Water Loss to Hours of Fever

The rate of fluid loss does not increase as high temperatures are prolonged. 


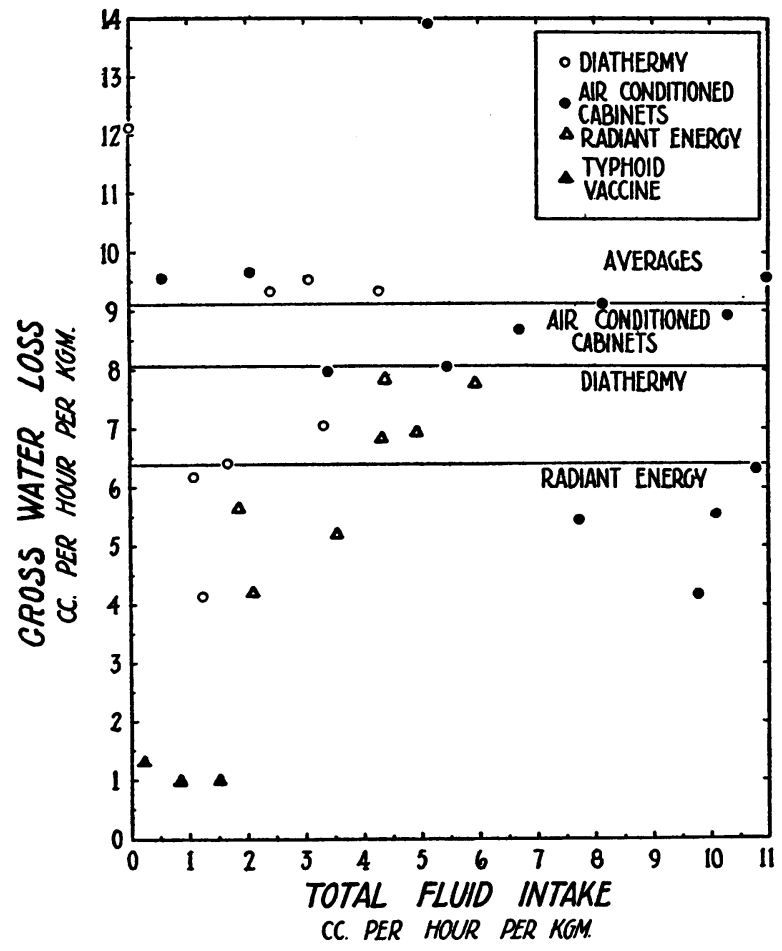

Fig. 4. Relationship of Gross Water Loss to Total Fluid INTAKe

The rate of gross water loss is not decreased by the administration of large amounts of fluid, by mouth or by vein.

ential temperature between the patient's body and his environment was highest, and least in those cases in whom it was lowest. No conclusive evidence was obtained in this study that relative humidity alone plays a decisive rôle. In patients treated in the "Kettering Hypertherm" the rate of gross water loss was the same, by and large, in those instances where the relative humidity was kept at 80 per cent as in those where it was only 40 per cent, and the relation of tissue fluid loss to rate of intake was the same (Cases D-1, $\mathrm{D}-2$, and 18 , and $\mathrm{D}-3,8$, and 13 , Table III). No measurements of relative humidity were obtained in the radiant energy cabinets in which the air was static, but it is doubtful if it was over 80 per cent at any time, and yet the rate of water loss was less than in the cases treated in the "Kettering Hypertherm." It seems significant that the dry bulb temperature of the air in the radiant energy cabinet could be dropped to nearly the patient's own temperature, whereas it had to be maintained around $120^{\circ} \mathrm{F}$. in the "Kettering Hypertherm " to obtain high humidity of the circulating air. In a moving air stream at a temperature of $120^{\circ} \mathrm{F}$. or above, even at a relative humidity of 80 per cent, evaporation can still occur.

The rate of loss or gain in tissue fluids is directly related to the rate of fluid intake as illustrated in Figure 5. It is striking that in all those cases, in which untoward effects were encountered, the loss of tissue fluid exceeded $5 \mathrm{cc}$. per hour per kgm. of body weight. This figure may be said to represent the limit of tolerance to loss of tissue fluid at high body temperatures.

Finally, it should be said that the assumption by many workers that the blood volume remains constant during artificial fever goes far toward invalidating their interpretations of changes in blood constituents. It must be evident that, if changes in the total blood volume of the magnitude we have shown to occur are not taken into account, simple determinations of the concentration of any blood constituent are meaningless as a basis for any understanding of the physiology of artificial fever.

\section{CONCLUSIONS}

1. Artificial fever produced by physical means is characterized by a large gross water loss from the blood stream by way of the skin and lungs.

2. The rate of water loss may be far more rapid than the rate of absorption from the intestinal tract or tissue spaces, resulting in varying degrees of reduction in plasma and total blood volume.

3. Water is lost most rapidly during the induction of fever during which the degree of reduction in blood volume is inversely related to the amount of fluid given, and directly related to the time required for elevation of temperature.

4. While individuals vary in their response to artificially induced high temperature, there exists for each individual a blood volume level beyond which further reduction in volume leads to peripheral vascular collapse.

5. The rate of gross water loss during maintenance is not directly related to the duration of fever or to the amount of fluid or the method by which it is administered, but is related to the difference in temperature between the patient's 


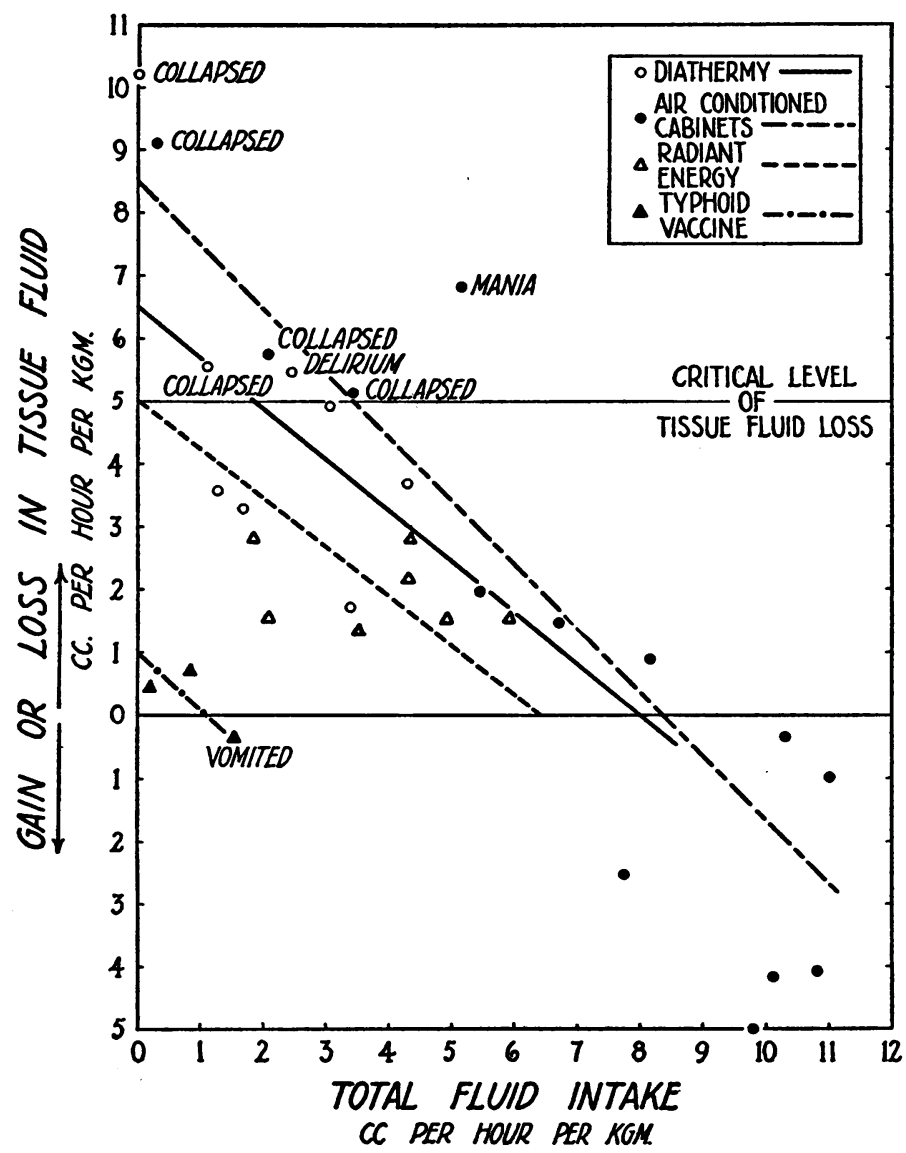

Fig. 5. Relationship between Changes in Tissue Fluid Volume and Total Fluid Intake

The amount of fluid withdrawn from or entering the tissue spaces is directly related to the rate at which fluids are given. A net loss of tissue fluid at a rate exceeding 5 cc. per hour per $\mathrm{kgm}$. of body weight cannot be tolerated at high temperatures.

body and the environmental air and to the relative humidity thereof.

6. The rate of loss of tissue fluids is directly related to the rate of fluid intake, and tissue fluid loss at a rate exceeding $5 \mathrm{cc}$. per hour per $\mathrm{kgm}$. involves the risk of serious collapse.

7. The prevention of shock in artificial fever therapy is dependent upon the giving of fluids in amounts and by routes adequate for the maintenance of the blood volume and water balance.

Grateful acknowledgment is made to Dr. H. C. Solomon for his encouragement and helpful suggestions in this work.

We wish to express our thanks to Dr. Stafford L. Warren and Mr. Francis Bishop of Strong Memorial Hospital, Rochester, New York, and to Dr. Walter M.
Simpson and Dr. H. Worley Kendell of the Miami Valley Hospital, Dayton, Ohio, for the opportunity to study patients in the cabinets used at their respective institutions, and for their helpful encouragement in this work.

\section{BIBLIOGRAPHY}

1. Simpson, W. M., Artificial fever therapy of syphilis and gonococcic infections. New York State J. Med., 1936, 36, 1290.

2. Owens, C. A., The value of fever therapy for gonorrhea. J. A. M. A., 1936, 107, 1942.

3. Stecher, R. M., and Solomon, W. M., The complications and hazards of fever therapy: Analysis of 1000 consecutive fever treatments with the Kettering hypertherm. Ann. Int. Med., 1937, 10, 1014.

4. Ebaugh, F. G., Barnacle, C. H., and Ewalt, J. R., Delirious episodes associated with artificial fever. Am. J. Psychiat., 1936, 93, 191. 
5. Neymann, C. A., Blatt, M. L., and Osborne, S. L., The treatment of chorea minor by means of electropyrexia. J. A. M. A., 1936, 107, 938.

6. Kopp, I., and Solomon, H. C., Shock syndrome in therapeutic hyperpyrexia. Arch. Int. Med., 1937, 60, 597.

7. Markson, D. E., and Osborne, S. L., The treatment of arthritis by electropyrexia. Illinois M. J., 1933, 64, 231.

8. Stecher, R. M., and Solomon, W. M., The treatment of gonorrheal arthritis with artificial fever. Am. J. M. Sc., 1936, 192, 497.

9. Bishop, F. W., and Horton, C. B., and Warren, S. L., A clinical study of artificial hyperthermia induced by high frequency currents. Am. J. M. Sc., 1932, 184, 515.

10. Sutton, L. P., and Dodge, K. G., The treatment of chorea by induced fever. J. Pediat., 1933, 3, 813.

11. Wilbur, E. L., and Stevens, J. B., Morbid anatomic changes following artificial fever, with report of autopsies. South. M. J., 1937, 30, 286.

12. Epstein, N. N., The blanket method of inducing artificial fever. Arch. Phys. Therapy, 1937, 18, 199.

13. Hartman, F. W., and Major, R. C., Pathological changes resulting from accurately controlled artificial fever. Am. J. Clin. Path., 1935, 5, 392.

14. Neymann, C. A., The effect of artificial fever on the clinical manifestations of syphilis and the treponema pallidum. Am. J. Psychiat., 1936, 93, 517.

15. Bierman, W., and Fishberg, E. H., Some physiologic changes during hyperpyrexia induced by physical means. J. A. M. A., 1934, 103, 1354.

16. Goldfeder, A., Radiothermy on oxygen content and capacity in human blood; the saturation point of hemoglobin with oxygen. Arch. Phys. Therapy, 1933, 14, 339.
17. Dennie, C. C., Polsky, M., and Lemoine, A. N., Hyperpyrexia produced by the hot bath in the treatment of syphilis. J. Missouri M. A., 1936, 33, 1.

18. Carpenter, C. M., and Warren, S. L., Artificially induced fever in the treatment of disease. New York State J. Med., 1932, 32, 997.

19. Feinberg, S. M., Osborne, S. L., and Afremow, M. L., A new method of nonspecific treatment of allergic disease. J. Allergy, 1931, 2, 291.

20. Phillips, K., and Shikany, S., The value of hyperpyrexia in the treatment of bronchial asthma. South. M. J., 1935, 28, 801.

21. McIntosh, R., On the effect of diathermy on blood volume. J. Physiol., 1931, 73, 361.

22. Knudson, A., and Schaible, P. J., Physiologic and biochemical changes resulting from exposure to an ultrahigh frequency field. Arch. Path., 1931, 11, 728.

23. Simpson, W. M., Studies on the physiology of fever. J. A. M. A. (Proc.), 1936, 106, 246.

24. Gibson, J. G., 2d, and Evans, W. A., Jr., Clinical studies of the blood volume. I. Clinical application of a method employing the azo dye "Evans blue" and the spectrophotometer. J. Clin. Invest., 1937, 16, 301.

25. Gibson, J. G., 2d, and Evelyn, K. A., Clinical studies of the blood volume. IV. Adaptation of the method to the photoelectric microcolorimeter. J. Clin. Invest., 1938, 17, 153.

26. Evelyn, K. A., and Cipriani, A. J., A photoelectric microcolorimeter. J. Biol. Chem., 1937, 117, 365.

27. Simpson, W. M., Artificial fever therapy of syphilis. J. A. M. A., 1935, 105, 2132.

28. Bishop, F. W., Lehman, E., and Warren, S. L., A comparison of three electrical methods of producing artificial hyperthermia. J. A. M. A., 1935, 104, 910. 